\title{
PERANCANGAN DAN SIMULASI TEGANGAN FRAME MESIN PENGISIAN CURAH TEMBAKAU
}

\author{
Desendra Aufana \\ Fakultas Teknik, Program Studi Teknik Mesin \\ Universitas Muria Kudus \\ Email : desendraaufana937@gmail.com \\ Masruki Kabib \\ Fakultas Teknik, Program Studi Teknik Mesin \\ Universitas Muria Kudus \\ Email : masruki.kabib@umk.ac.id \\ Taufiq Hidayat \\ Fakultas Teknik, Program Studi Teknik Mesin \\ Universitas Muria Kudus \\ Email : taufiq.hidayat@umk.ac.id
}

\begin{abstract}
ABSTRAK
Mesin pengisian curah tembakau merupakan mesin pengisian rajangan tembakau yang sudah dicampur dengan bahan-bahan lain untuk dimasukkan ke dalam bin. Mesin pengisian curah tembakau berfungsi untuk mengisikan curah tembakau dan meratakan curah tembakau ke dalam bin. Frame merupakan komponen utama dari mesin pengisian curah tembakau. Penelitian ini beertujuan merancang frame mesin pengisian curah tembakau dan menganalisa simulasi frame tengangan von mises stress. Metode yang digunakan meliputi studi literatur, proses perancangan dan analisa silmulasi tegangan. Hasil perancangan adalah desain frame yang mampu menopang beban dengan tegangan von mises $0,116 \mathrm{MPa}$ dan displacement $0,00034 \mathrm{~mm}$. Hasil simulai menunjukan bahwa tengangan von mises yang terjadi pada frame mengalami Max : 0.113243 $\mathrm{Mpa}$, dan displacement $0.000870669 \mathrm{~mm}$. Hasil perhitungan tegangan von mises lebih besar dari hasil simulasi dan perhitungan displacement lebih kecil dari hasil simulasi.
\end{abstract}

Kata kunci : curah tembakau, frame, simulation, displacement

\section{ABSTRACT}

Tobacco bulk filling machine is a tobacco chop filling machine that has been mixed with other ingredients to be put in a bin. Tobacco bulk filling machine functions to fill the tobacco bulk and flatten the tobacco bulk into the bin. The frame is a major component of the tobacco bulk filling machine. This study aims to design a tobacco bulk filling machine frame and analyze von misses stress frame simulation. The methods used include literature study, design process and stress simulation analysis. The design result was a frame design that is able to support the load with a von misses voltage of $0.116 \mathrm{MPa}$ and displacement of $0.00034 \mathrm{~mm}$. The results of simulations was indicate that the von misses gap that occurs in the frame experiences Max: $0.113243 \mathrm{MPa}$, and displacement $0.000870669 \mathrm{~mm}$. The von misses stress calculation results were greater than the simulation results and the displacement calculations are smaller than the simulation results.

Keywords : bulk tobacco, frame, simulation, displacement. 


\section{PENDAHULUAN}

Mesin pengisian curah tembakau merupakan suatu alat atau perkakas yang di gunakan untuk mengisikan curah tembakau dari conveyor yang terdapat hopper pengarah kedalam bin wadah curah tembakau yang telah ditentukan. Pengisian curah yang baik, maka ukuran mulut bin dan ukuran hopper pengarah harus sesuai, dengan kemampuan dari curah tembakau untuk dapat melewati hopper tanpa terhambat dan kecepatan motor untuk menggerakkan hopper [1].

Frame merupakan bagian dari mesin pengisian curah tembakau yang berfungsi menompang beban komponen-komponen frame di syaratkan harus kuat, kokoh tahan terhadap api dan tahan terhadap getaran atau goncangan, Frame yang kuat selama proses produksi yang pada dasarnya akan menahan beban pengisian curah tembakau lebih dari $10 \mathrm{~kg}$ serta mampu meredam getaran dari motor. Guna memenuhi kebutuhan sesuai dengan cara kerja mesin pengisian curah tembakau yang telah direncanakan, maka dibuat desain frame mesin pengisian curah tembakau yang dapat mendukung cara kerja mesin [2].

Pengembangan desain frame yang telah dilakukan penelitian sebelumnya menunjukan bahwa frame memiliki kekurangan yaitu kaki kurang tegak diakibatkan karena kurang ketelitian pada saat pemotongan sudut kaki-kaki frame. Pada saat perakitan kaki-kaki frame juga sedikit mengalami pelengkungan akibat arus las. Adanya cacat las pada frame. Cacat las diakibatkan karena penggunaan arus yang tidak sesuai dan elektroda yang lembab. Ukuran tidak sesuai dengan gambar kerja. Ukuran-ukuran tersebut berbeda akibat pemuaian dan pelengkungan pada saat perakitan bahan menggunakan las busur listrik [3].

Pengembangan desain frame mesin pencacah rumput laut dengan menggunakan metode rancang bangun, desain frame yang sudah direncanakan telah dibuat kosepnya menggunakan sofware AutoCad 2013. Selajutnya, desain frame yang telah dibuat diberi ukuran mengguanakan AutoCad 2013 dengan satuan ukuran milimeter ukuran frame 1 mesin pencacah rumut laut skala $\mathrm{ukm}$. Perancangan frame mesin pencacah rumput laut ini masih ada beberapa kekurangan, baik dari segi kualitas bahan, penampilan, dan kerja/fungsi. Oleh karena itu, untuk dapat menyempurnakan rancangan mesin ini perlu adanya desain yang lebih baik lagi [3].

Desain frame mesin perajang ubi horizontal berfungsi untuk menompang seluruh komponen alat perajang. Frame ini terbuat dari besi siku 3x3 dengan ketebalan $3 \mathrm{~mm}$. Pemilihan besi siku dengan ukuran tersebut karena alasan teknis harus dapat menopang sistem penggerak (motor listrik) dan sistem transimisi (pully) serta alasan ketersediaan di pasaran. Pembuatan frame ini tidak mengalami perubahan dan perbaikan bentuk untuk dari perncanaan awal, dan secara fungsional desain frame berfungsi baik dan kokoh. Perajang ubi kayu pisau berggerak melalui motor listrik berhasil dikontruksi dan berfungsi baik serta dioperasikan dengan nyaman [4].

Analisa statik yang telah dilakukan terhadap frame mesin dengan cara memberikan beban terpusat pada bagian-bagian komponen yang berperan dalam sistem kerja mesin maka diperoleh hasil analisa statik yang menunjukan tegangan (von misses stress) minimum serta maksimum, peralihan ( displacement) minimum serta maksimumnya peran penting dalam perancangan mesin pencacah rumput gajah diantaranya tidak lepas dari segi kekuatan, dimana rumput yang akan dicacah. Analisa pembebanan statik yang dilakukan pada frame tersebut telah dilakukan pada frame mesin dan material frame yang dipakai adalah baja kontruksi S 10 C ( AISI 1010 ). Adapun hasil dari beberapa pembebanan tersebut menghasilkan tegangan von mises maksimal 3,42 x $10^{7}$ $\mathrm{N} / \mathrm{m}^{2}$ dengan nilai peralihan maksimal sebesar $0,00985 \mathrm{~mm} \mathrm{[5].}$

Berdasarkan hasil perhitungan, pemodelan dan simulasi dengan metode elemen hingga untuk pengujian kekuatan dies frame link dengan software inventor pada proses pembengkok pipa 2 in diperoleh tegangan principal 145,5 $\mathrm{MPa}$ lebih kecil dari perhitungan tegangan bengkok pada frame adalah 2130,525 MPa.Nilai displacement 0,008829 $\mathrm{mm}$ lebih kecil dari perhitungan defleksi pada frame adalah $0,0435 \mathrm{~mm}$., dannilai tegangan von mises $147,5 \mathrm{MPa}$. Lebih kecil dari perhitungan besarnya Von mises pada frame adalah 2130,528 MPa. [6].

Berdasarkan hasil dari simulasi analisa tegangan screw conveyor dengan metode elemen hingga untuk pencampur garam dan iodium yang menggunakan jenis material stainless steel 304, menghasilkan distribusi tegangan keseluruh screw conveyor. Hasil analisis di dapatkan nilai 
displacement maksimal sebesar 0,0792 mm. Tegangan Von misses maksimum 8,16969 MPa dan safety factor 15 ul. Sehingga dapat dinyatakan screw conveyor memenuhi syarat dan aman untuk proses pencampuran garam dan iodium [7].

Penelitian ini bertujuan merancang dan analisa simulasi tegangan pada von mises, displacement frame pada mesin pengisian curah tembakau masih perlu adanya penyempurnaan atau perbaikan dari proses pengoprasian sebelumnya masih menggunakan sistem secara manual [8].

Desain dan analisis frame mesin pengisian curah tembakau ini akan dilakukan proses penyempurnaan dari perancangan frame. Dimana untuk proses perancangan frame pada mesin pengisian curah tembakau ini akan dilakukan proses simulasi untuk mencari nilai von mises stress dan displacement dari tegangan nilai tersebut [9] [10].

\section{METODOLOGI PENELITIAN}

Proses perancangan frame mesin pengisian curah tembakau digunakan untuk massa $10 \mathrm{~kg}$ dan dilakukan dengan perancangan dan simulasi dengan langkah - langkah sebagaimana di tunjukan gambar 1 dibawah ini :

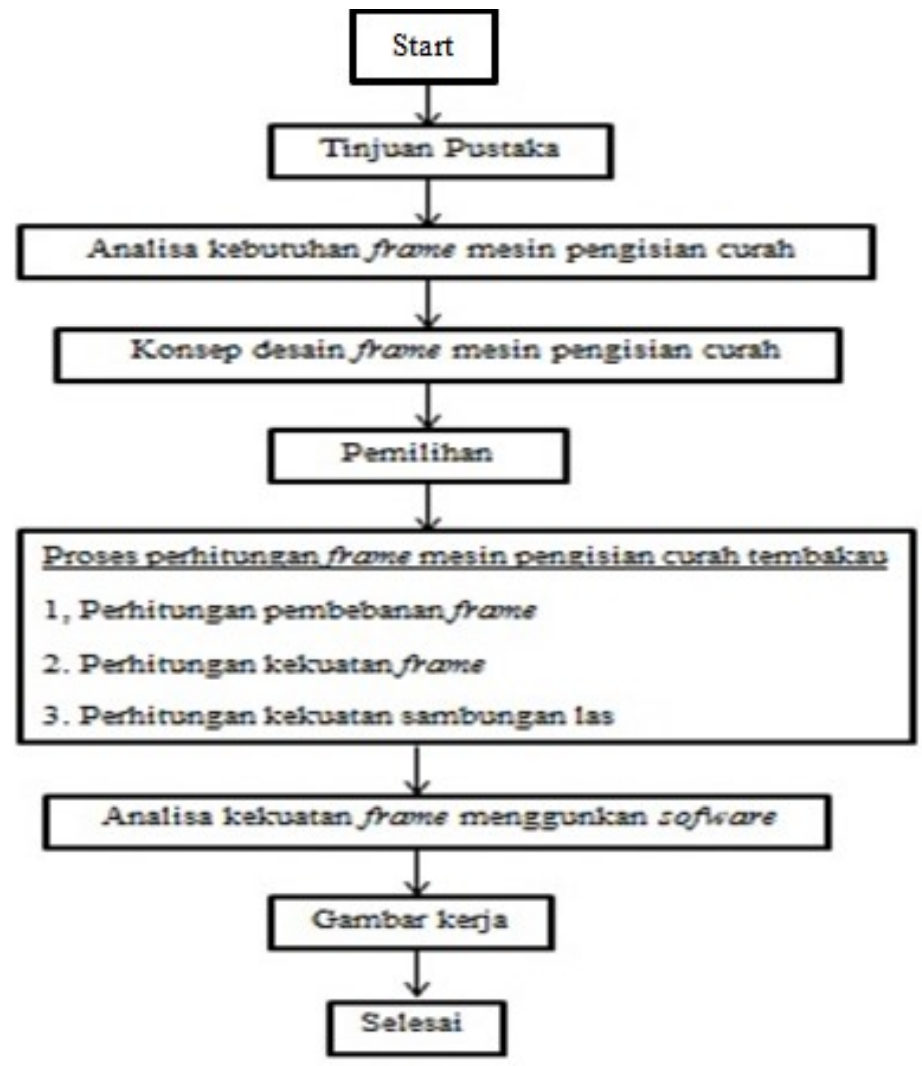

Gambar 1. Diagram alir rancang bangun

Langkah - Langkah penelitian sebagaimana gambar di mulai dengan kajian pustaka selanjutnya dilakukan analisa kebutuhan ada dua konsep desain analisa kekuatan frame. pemilihan konsep frame mesin pengisian curah tembakau sesuai dengan kebutuhan supaya dapat menghasilkan mesin yang maksimal. Proses perhitungan frame ini dilakukan dengan perhitungan pembebanan,perhitungan kekuatan frame, perhitungan sambungan las agar dapat mengetahui nilai dari perhitungan tersebut. Analisa kekuatan frame menggunakan sofware ini dengan menggunakan 
simulasi stress analysis dan frame analysis dengan menentukan titik yang akan dilakukan stress analysis. Gambar kerja digunakan sebagaimana dapat mengetahui frame yang akan dibuat.

\section{HASIL DAN PEMBEHASAN}

\subsection{Konsep Desain}

Konsep frame dirancang ada dua konsep frame mesin pengisian curah tembakau dengan menggunakan sistem otomatis dengan didasari oleh perhitungan dan ukuran. Konsep frame yang dilakukan dalam sebuah mesin pengisian curah tembakau menggunakan sistem kontrol harus kuat karena harus menahan beban-beban komponen yang berada di dalam mesin sehingga konsep tersebut dapat diaplikasikan ke dalam sebuah mesin pengisian curah tembakau, dapat dilihat pada gambar 2 dan 3 dibawah ini :

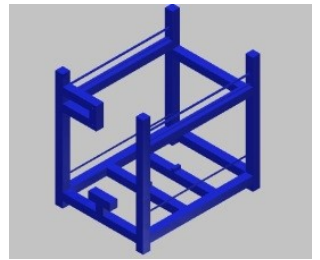

Gambar 2. Konsep 1

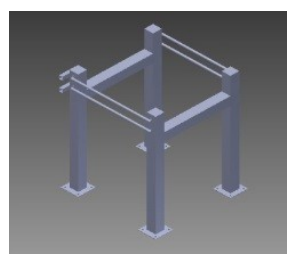

Gambar 3. Konsep 2

Pemilihan konsep desain mempertimbangkan perbedaan maka tingkat efisiensi dan kekuatan cenderung kepada konsep yang pertama karena lebih kuat untuk mesin pengisian curah tembakau dengan massa $10 \mathrm{~kg}$ dengan pertimbangan sebagai berikut :

Desain Frame utama berada di tengah frame dilakukan dengan cara pengelasan agar pada saat di bebani oleh komponen-komponen mesin pengisian curah tembakau dengan massa $10 \mathrm{~kg}$ tidak terjadi bergeseran membuat kontruksi frame menjadi lebih kuat dan menjadikan biaya pembuatan mesin bisa di minimalisir. Frame menggunakan square pipe dengan ketebalan $3 \mathrm{~mm}$ sehingga frame kuat karena mampu menahan getaran. Frame bawah menggunakan Baja profil siku ST 37. Aksebilitas operator sangat baik Karena di mudahkan dengan desain dalam penempatan bin yang tidak terlalu tinggi. Dari kekuatan kontruksi kedua desain mempunyai defleksi yang sama yaitu defleksi vertikal. Kemudahan pada proses manufaktur dilakukan dalam waktu yang sudah di tentukan.

Frame yang berfungsi untuk menyangga dan tempat berbagai komponen - komponen mesin pengisian curah tembakau dengan massa $10 \mathrm{~kg}$, mengalami pembebanan yaitu hopper, bin, roda, motor pendorong hopper,lengan pendek engkol penggerak hopper,lengan panjang pendorong hopper,motor pendorong bin,lengan pendek pendorong bin,lengan panjang pendorong bin,buka tutup hopper.

\subsection{Perhitungan kekuatan frame}

Pada proses perencanaan perhitungan frame pada mesin pengisian curah tembakau dibutuhkan proses perhitungan untuk mempermudah proses pembuatan atau perencanaan. Dalam proses perhitungan frame meliputi perhitungan pembebanan frame, perhitungan kekuatan frame, perhitungan kekuatan sambungan las.

Perhitungan kekuatan frame di dasarkan sebagaimana ditujukan pada gambar 4 : 


\subsection{Perhitungan frame}

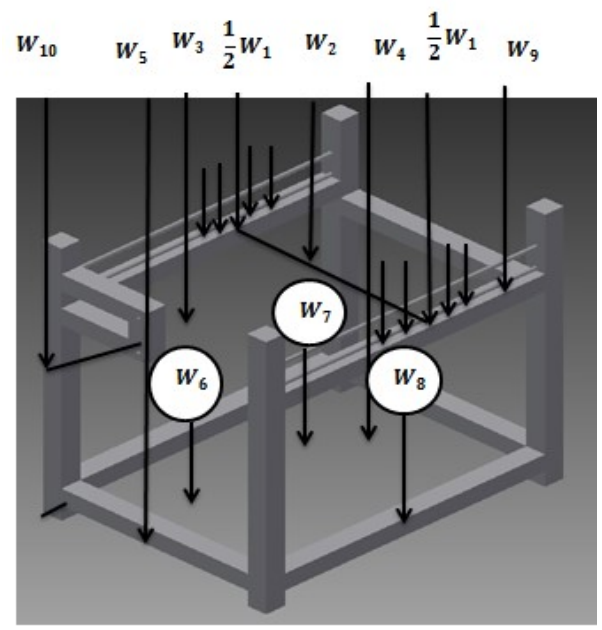

Gambar 4. frame pembebanan

Perencanaan perhitungan pembebanan frame daya bertujuan untuk menentukan seberapa maksimal yang didapat dari mesin pengisian curah tembakau.

Beban pada frame dihitung dengan menggunakan 1 persamaan berikut [3] :

$\mathrm{W}=\mathrm{m} \cdot \mathrm{g}$

Di mana $\mathrm{W}$ adalah gaya $(\mathrm{N})$, m adalah massa dalam $(\mathrm{kg})$, g adalah gaya gravitasi $\left(\mathrm{m} / \mathrm{det}^{2}\right)$.

Perhitungan kekuatan frame dengan memberikan beban terpusat pada bagian komponen yang berperan dalam sistem kerja mesin dapat dihitung dengan menggunkan persamaan 2 berikut [3] :

$\sum M_{A}=0$

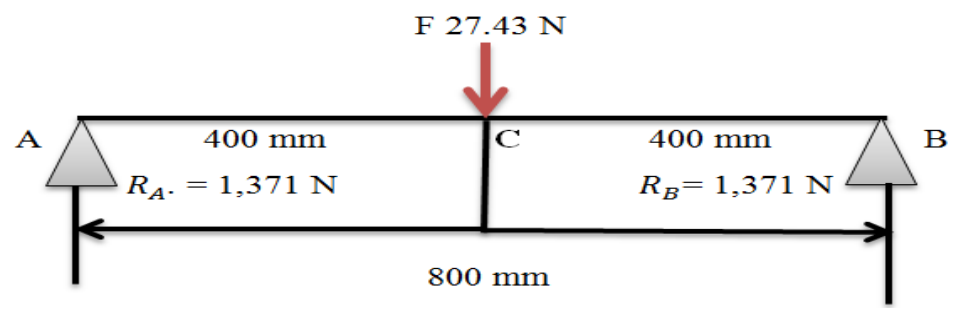

Gambar 5. kekuatan frame atas

Perhitungan kekuatan sambungan las pada frame mesin pengisian curah tembakau ini hanya ditinjau dari pengelasan pada frame karena dapat melihat sambungan pada tegangan tarik ijin dapat dihitung dengan menggunkan persamaan 3 berikut [5] :

$f_{v}=\frac{p}{0,0707 a L_{W}}$

Dimana $f_{v}$ adalah tegangan tarik ijin, $\mathrm{P}$ adalah massa total. 


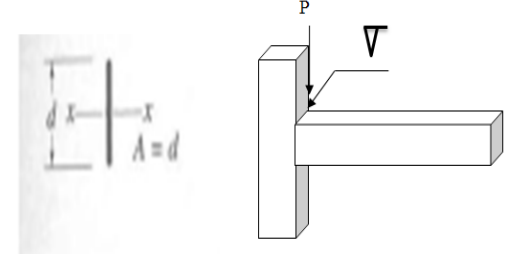

Gambar 6. Sambungan pengelasan

E $60,000=$ kekuatan tarik terendah setelah di laskan adalah 60,000 psi atau $420 \mathrm{~N} / \mathrm{mm}$ dengan posisi pengelasan mendatar, vertical atas kepala dan horizontal jenis listrik adalah DC polaritas balik (DC+) diameter elektroda $2,5 \mathrm{~mm}$, arus $90-150 \mathrm{~A}$.

Ditinjau dari tegangan (momen bending) pada frame untuk mencari kekuatan tarik ijin dapat dihitung dengan menggunakan persamaan 4 pada tengangan dapat dihitung menggunakan persamaan 4 berikut [13] :

$$
\sigma_{\max }=\frac{M_{\max Y}}{I}
$$

Dimana Momen bending maksimal adalah ( $\left.M_{\max }\right)$,Momen inersia adalah (Ix), Jarak dari sumbu netral adalah (y).

Defleksi adalah perubahan bentuk pada balok dalam arah y akibat adanya pembebanan yang diberikan pada balok atau batang dapat dihitung dengan menggunakan persamaan 5 berikut [6] :

$$
\delta=\frac{\mathrm{P} \cdot \mathrm{L}}{\mathrm{A} \cdot \mathrm{E}}
$$

Dimana Defleksi yang terjadi adalah $(\delta)$, Panjang bahan adalah $(\mathrm{P})$, Luas penampang adalah (A), Modulus elastisitas adalah (E)

Von mises stress untuk mencari keuletan bahan ketika invarian tegangan deviatorik kedua mencapai nilai keritis dapat dihitung menggunakan persamaan 6 berikut [6] :

$$
\begin{aligned}
& \sigma \max =\frac{\sigma_{x}+\sigma_{y}}{2}+\sqrt{\left(\frac{\sigma_{x}+\sigma_{y}}{2}\right)^{2}+\left(\tau_{x y}\right)^{2}} \\
& \sigma \min =\frac{\sigma_{x}+\sigma_{y}}{2}-\sqrt{\left(\frac{\sigma_{x}+\sigma_{y}}{2}\right)^{2}+\left(\tau_{x y}\right)^{2}}
\end{aligned}
$$

Dimana $\sigma_{x}=\sigma$ dan $\sigma_{y}=0$

Hasil perhitungan kekuatan dan dimensi frame ditunjukkan pada tabel 1.

Tabel 1. Hasil perhitungan pada frame mesin pengisian curah tembakau

\begin{tabular}{lc}
\hline \multicolumn{1}{c}{ Perhitungan } & Hasil \\
\hline 1.Perhitungan kekuatan pada frame & $1.371 \mathrm{Nmm}$ \\
2.kekuatan sambungan las & $0,143 \mathrm{~N} / \mathrm{mm}^{2}$ \\
3.Tegangan momen bending pada batang & $1,266 \mathrm{~N} / \mathrm{mm}^{2}$ \\
5.Von mises stress & $0,166 \mathrm{Mpa}$ \\
6.Displacement & $0,00034 \mathrm{~mm}$ \\
\hline
\end{tabular}




\subsection{Simulai pada frame atas}

Frame bagian atas mesin pengisian curah tembakau mendapatkan pembebanan tarik pada 2 sisi atas frame. Nilai pembebanan yang di berikan $54,87 \mathrm{~N}$ di bagian dua sisi yaitu $27.43 \mathrm{~N}$ Hasil analisa menggunakan sofware inventor 2015 adalah sebagaimana ditunjukkan pada gambar 7 dan 8 berikut :

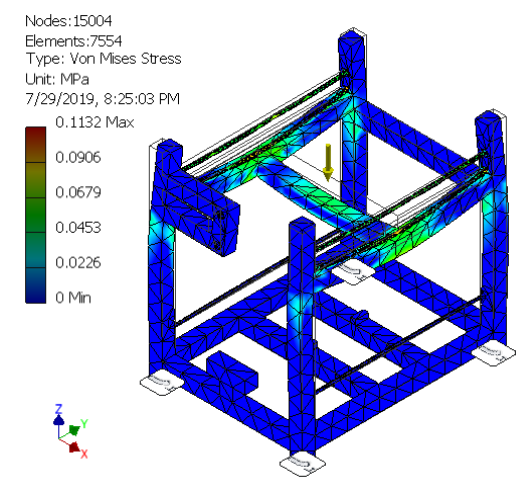

Gambar 7. simulasi frame atas von misesstress

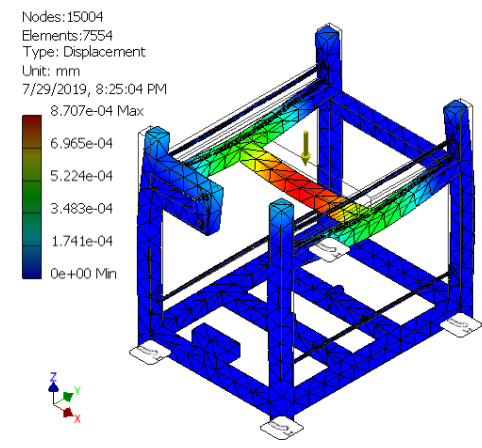

Gambar 8. Simulasi frame displacement

Pada proses pengujian dengan menggunakan sofware inventor 2015 pada frame atas mengalami von mises min : $0.00000165356 \mathrm{Mpa}$ dan Max : $0.113243 \mathrm{Mpa}$, displacement min : 0 $\mathrm{mm}$ dan nilai max : $0.000870669 \mathrm{~mm}$, dan nilai $\geq 1$ sehingga frame dinyatakan aman dan masih memenuhi alat yang ditentukan.

Pembebanan pada frame sebagian besar ditahan oleh batang melintang yang di tengah, hal ini disebabkan pada bagian tersebut menerima beban hopper dan tembakau yang masuk ke dalam hopper. Hasil simulasi menunjukkan bahwa pada bagian ini masih memenuhi syarat kekuatan desain rangka.

\section{KESIMPULAN}

Dari hasil perhitungan frame mesin pengisian curah tembakau dan mengetahui pengujian kekuatan tengangan von mises stress yang terjadi pada frame dengan hasil perhitungan menunjukan bahwa tegangan von mises yang terjadi mencapai Max : $0,116 \mathrm{MPa}$, dan displacement $0,00034 \mathrm{~mm}$. Hasil simulasi menunjukkan bahwa tegangan von misses yang terjadi pada frame mencapai Max : $0.113243 \mathrm{Mpa}$, dan displacement $0.000870669 \mathrm{~mm}$. Hasil 
perhitungan tegangan von mises lebih besar dari hasil simulasi dan perhitungan displacement lebih kecil dari hasil simulasi

\section{DAFTAR PUSTAKA}

[1] Anefin Dwima, Kasatriawan, 2012,"Proses Pembuatan Rangka Pada Mesin Perajang Sampah Organik Sebagai Bahan Dasar Pupuk Kompos," Proyek akhir, Pendidikan Teknik Mesin, Universitas Negeri Yogyakarta .

[2] April Yanto Wibowo, 2011, "Proses Pembuatan Rangka Pada Mesin Roll Pelat Penggerak Elektrik," Proyek akhir, Pendidikan Teknik Mesin, Universitas Negeri Yogyakarta.

[3] E. Widya P., 2015, "Rancang Bangun Mesin Pencacah Rumput Laut Skala Ukm," Jurnal Rekayasa Mesin, Vol. 2 No. 2 Pp. 11-16.

[4] M. Lutfi, S. Setiawan, W. A. Nugroho, T. Pertanian,2010, "Rancang Bangun Perajang Ubi Kayu Pisau Horizontal," Rekayasa Mesin, Vol. 1, No. 2, Pp. 41-46.

[5] Indra Gunawan, 2009 "Perencanaan Mesin Dan Analisa Statik Rangka Mesin Pencacah Rumput Gajah Dengan Menggunakan Software Catia V5," Skripsi, Program Studi Teknik Mesin, Universitas Gunadharma .

[6] S. Kuntoro, M. Kabib, 2018, "Analisis Kekuatan Dies Frame Link Pada Mesin Roll Pipa 2 In Penggerak Hidrolik Dengan Metode Elemen Hingga,” Jurnal SIMETRIS,. Tek. Mesin, Elektro Dan Ilmu Komput., Vol. 9, No. 2, Pp. 941-946.

[7] A. Rofeg, M. Kabib, 2018, "Analisa Tegangan Screw Conveyor Pada Mesin Pencampur Garam Dan Iodium sesuai SNI 3556 dengan Metode Elemen Hingga”, Jurnal SIMETRIS, Vol. 9, No. 2, Pp. 935-940.

[8] F. Albaha, 2011, "Proses Pembuatan Rangka Pada Mesin Perajang Daun Tembakau," Proyek Akhir, Pendidikan Teknik Mesin, UNY.

[9] N. Adi P, 2018 "Rancang Bangun Rangka Mesin Pemotong Makanan Ringan (Dodol) Kapasitas $70 \mathrm{Kg}$," Tugaas Akhir, Teknik Mesin, UMK.

[10] A. Tri Lestari, 2010, "Pembuatan Alat Praktikum Perawatan Kompresor Torak Ganda," Proyek Akhir, Teknik Mesin, UNS . 